\title{
RELACIJE NEKIH OSOBINA LIČNOSTI I KARAKTERISTIKA SPORTISTA SA SPORTSKOM ANKSIOZNOŠĆU
}

\author{
Dejana Velikić ${ }^{1}$ Jasmina Knežević ${ }^{1}$ i Nadežda Rodić ${ }^{1}$
}

${ }^{1}$ Visoka škola strukovnih studija za obrazovanje vaspitača i trenera, Subotica, Srbija

\section{SAŽETAK}

Sportska anksioznost predstavlja tendenciju da se situacije takmičenja procenjuju kao preteće, a kao odgovor na ovakvu situaciju javlja se anksiozno stanje. Kako istraživanja kontinuirano ukazuju na vezu između anksioznosti i sportskog postignuća, problem istraživanja je: da li postoji povezanost osobina ličnosti sportista sa stepenom anskioznosti kod sportiste, kao i da li postoje razlike u stepenu anksioznosti u odnosu na pol sportiste, vrstu sporta i nivo sportske uspješnosti. Cilj istraživanja je unapređenje razumjevanja o ličnim i situacionim faktorima koji su povezani sa anksioznošću kod sportista. Pošlo se od multidimenzionalne teorije anksioznosti koja razlikuje somatsku komponentu anksioznosti, kognitivnu komponentu i samopouzdanje. U istraživanju je učestvovalo 90 sportista, koji su procenjivali: stepen izraženosti stanja sportske anksioznosti pomoću skale CSAI-2 i osobine ličnosti (VP+2). Nalazi potvrđuju osobine ličnosti kao prediktore somatske anksioznosti, pri čemu se agresivnost izdvojila kao značajan prediktor somatske anksioznosti. Neuroticizam, agresivnost i otvorenost ka iskustvu izdvojili su se kao prediktori kognitivne anksioznosti, a savjesnost, agresivnost i otvorenost ka iskustvu kao prediktori sportskog samopouzdanja.

Ključne riječi: multidimenzionalna teorija anksioznosti, osobine ličnosti sportska anksioznost.

\section{UVOD}

Sportski rezultati svakodnevno potvrđuju da fizička kompetencija i fizička spremnost nisu dovoljni faktori za uspjeh u sportu. Podjednako važni, ako ne i važniji, su brojni psihološki faktori: osobine ličnosti, samopouzdanje, sportska anksioznost itd. U skladu sa ovim, cilj istraživanja je da unaprijedi razumjevanje o ličnim i situacionim faktorima koji su povezani sa anksioznošću kod sportista. Utvrđivanje veze između anksioznosti i sportskog postignuća bilo je predmet brojnih istraživanja (Feltz, 1988; Gould, Petlichkoff i Weinberg, 1984; Martens, Burton, Vealey, Bump i Smith, 1990). Weinberg i Gould određuju anksioznost kao negativno emocionalno stanje koje karakteriše nervoza, briga, kao i aktivacija i pobuđenost samog tijela (Weinberg \& Gould, 1996; prema Pineda-Espejel, López-Walle, Rodríguez, Villanueva i Gurrola, 2011). U kontekstu sportskog takmičenja javlja se određena vrsta anksioznosti - sportska, odnosno, kompetitivna anksioznost. Kod sportske anksioznosti neophodno je razlikovati dvije dimenzije: sportska anksioznost kao stanje i sportska anksioznost kao crta ličnosti. Martens definiše crtu sportske anksioznosti kao tendenciju da se situacije takmičenja procjenjuju kao preteće, pri čemu, kao odgovor na ovakvu situaciju, nastaje anksiozno stanje (Martens 2007; prema, Behzadi, Hamzei, Nori i Salehian, 2011). Sportsko stanje anksioznosti odnosi se na emocionalno stanje straha i napetosti vezano za određenu sportsku situaciju (Vujanović i Tišma, 2011). Istraživanja kontinuirano pokazuju da visok nivo sportske anksioznosti ometa postignuće sportiste (Behzadi i saradnici, 2011; Craft, Magyar, Beckern i Feltz, 2003; Pineda-Espejel i saradnici, 2011). U mnogim istraživanjima, anksioznost je posmatrana kao jednodimenzionalan konstrukt, međutim, Martens i saradnici (1990) ukazuju da je sportska anksioznost multidimenzionalni konstrukt. U skladu sa takvim pristupom, isti autori postavljaju multidimenzionalnu teoriju anksioznosti. Prema ovoj teoriji, anksioznost obuhvata somatsku komponentu, kognitivnu komponentu i samopouzdanje. Somatska anksioznost se odnosi na tjelesne simptome koji se javljaju kod sportiste (lupa- 
nje srca, znojenje dlanova, bolovi u mišićima itd.). Kognitivna anksioznost je mentalna komponenta anksioznosti i nastaje kao rezultat negativnih očekivanja i nedostatka sigurnosti u sebe i sopstvene sposobnosti (Pineda-Espejel i saradnici, 2011). Upravo je kognitivna anksioznost (briga), često prepoznata kao ključni konstrukt sportske anksioznosti (Bridges i Knight, 2005; Dunn i Dunn, 2001). Kognitivna anksioznost je najčešće orjentisana na budućnost, javlja se kada se pažnja usmjeri na očekivane izvore opasnosti, odnosno potencijalni neuspeh (Bridges \& Knight, 2005; Dunn \& Dunn, 2001; Humara, 1999). Iščekivanjem neuspjeha, sportista fokus pažnje usmjerava na ono što ne može, na svoje nedostatke, a ne na sopstvene potencijale i na ono šta može da učini. Samim tim, sportista otežava sposobnost da ostane smiren i „hladne glave“ u ključnim situacijama. Istraživanja pokazuju negativnu vezu između kognitivne anksioznosti i sportskog postignuća (Hardy i Carce, 2009; Humara, 1999). Odsustvo sportskog samopouzdanja, iako nije direktna mjera anksioznosti, rezultuje većim stepenom kognitivne anksioznosti. Odnos sportskog samopouzdanja i postignuća pokazao se kao pozitivan, dok se odnos između somatske anksioznosti i postignuća može objasniti krivom obrnutog slova U (Humara, 1999).

Za sportsko postignuće neophodan je određeni nivo pobuđenosti organizma; previše visok ili previše nizak nivo pobuđenosti negativno će djelovati na postignuće. Istraživači su ispitivali uticaj interakcije između somatske i kognitivne anksioznosti na postignuće sportiste. Kada je kognitivna anksioznost niska, sama fiziološka pobuđenost nema uticaja na postignuće (Ibid). Međutim, kako raste kognitivna anksioznost, fiziološka pobuđenost može imati pozitivan ili negativan efekat na postignuće, u zavisnosti od stepena pobuđenosti (Ibid). Očekivano, veći stepen pobuđenosti negativno utiče na učinak sportiste. Važnu ulogu igra i samopouzdanje, odnosno vjera u sopstvene vještine i sposobnosti. Samo stanje pobuđenosti imaće negativan efekat na postignuće, ukoliko postoji sumnja u sopstvene sposobnosti i procena da izazov prevazilazi postojeće kapacitete (Hardy i Crace, 2009). $\mathrm{Na}$ nivo kognitivne anksioznosti utiče $\mathrm{i}$ iskustvo, odnosno dužina bavljenja sportom. Iskusniji sportisti izveštavaju o nižem stepenu kognitivne anksioznosti, kao i o većem stepenu sportskog samopouzdanja (Humara, 1999). Istraživanja pokazuju značajniji uticaj sportskog samopouzdanja na postignuće, nego na anksioznost. Prednost koju imaju vrhunski sportisti u nastajanju kognitivne anksioznosti jeste upravo njihovo samopouzdanje koje djeluje kao protektivni faktor (Hardy, 1996). Takođe, istraživanja pokazuju razlike između sportista koji se bave individualnim i kolektivnim sportom. Veći stepen somatske anksioznosti i niže sportsko samopouzdanje je potvrđeno na uzorku sportista koji se bave individualnim sportom, u poređenju sa onima koji se bave kolektivnim sportom (Humara, 1999; Kirby i Liu, 1999). Objašnjenje za ovo nalazi se u podjeljenoj odgovornosti u timskim sportovima, u odnosu na individualne sportove ( $\mathrm{Hu}-$ mara, 1999), odnosno, u različitom referentnom okviru koji ovi sportisti imaju (timski nasuprot individualnom okviru). Slični nalazi su dobijeni poređenjem muškaraca i žena. Žene imaju niži stepen samopouzdanja i veći stepen somatske i kognitivne anksioznosti u odnosu na muškarce. Objašnjenje ovakvih nalaza je da žene, za razliku od muškaraca, u većoj meri sumnjaju u sebe i sopstvene sposobnosti (Humara, 1999; Pineda-Espejel et al., 2011). Takođe, kognitivna i somatska anksioznost, kod muškaraca, su povezane sa procjenom sposobnosti suparnika i procjenom vjerovatnoće pobjede. Kod žena, kognitivna anksioznost i sportsko samopouzdanje, povezani su sa procjenom pripremljenosti za takmičenje i značajem pobjede (Jones, Swain i Cale, 1991).

Osobine ličnosti takođe doprinose anksioznosti. Predispozicije ličnosti koje se najčešće pominju kao osnova negativnih emocionalnih reakcija (među kojima je i anksioznost), jesu ekstraverzija i neuroticizam (Marić, 2010). Neuroticizam je povezan sa negativnim afektivitetom, odnosi se na sklonost doživljavanja negativnih emocija, uključujući i anksioznost (Marić, 2010; Tran, 2012). Ekstraverzija je povezana sa pozitivnim afektivitetom i optimizmom. Ekstraverte karakteriše nizak nivo kognitivne aktivacije, pa im je neophodan veći broj stimulusa, što rezultuje većom bihejvioralnom aktivnošću (Smederevac, Mitrović i Čolović, 2010). Međutim, na suprotnom polu se nalaze intoverti koji ispoljavaju suprotno ponašanje $\mathrm{i}$ afektivitet (Knežević, Radović i Opačić, 1997; Marić, 2010; Smederac i saradnici, 2010). Introverte karakteriše visok nivo kognitivne pobuđenosti, stoga oni izbegavaju preteranu stimulaciju što rezultuje bihejvioralnom inhibicijom (Smederac i saradnici, 2010). Istraživanja pokazuju da je kombinacija visokog neuroticizma i niske ekstraverzije prediktor opšte anksioznosti, straha od neuspeha i depresije na uzorku studenata (Gershuny i Sher, 1998; Komarraju, Karau i Schmeck, 2009; Matsudaira i Kitamura, 2006; Middeldorp i sardnici, 2006). Samim tim, može se očekivati slična kombinacija osobina kod sportista koji ispoljavaju veći stepen sportske anksioznosti. Savjesnost se pokazala kao negativan prediktor sportske anksioznosti (Matsumoto, Takeuchi, Nakajima i Iida, 2000); sportisti koji imaju izraženu savjesnost, su u većoj 
mjeri istrajniji u treniranju, samim tim imaju više samopouzdanja i manje su anksiozni. Na sličan, ali obrnut način deluje neuroticizam, koji za posljedicu ima nisko samopouzdanje i visoku anksioznost. Istraživanja takođe pokazuju povezanost ekstraverzije i sportskog samopouzdanja, koji zajedno čine prediktore sportskog postignuća (Matsumoto i saradnici, 2000).

U skladu sa navedenim, problem istraživanja definisan je u vidu pitanja: da li postoji povezanost osobina ličnosti sportista sa stepenom anskioznosti kod sportiste, kao i da li postoje razlike u stepenu anksioznosti u odnosu na pol sportiste, vrstu sporta i nivo sportske uspješnosti.

Uzimajući u obzir nalaze prethodno navedenih istraživanja, osnovne pretpostavke ovog istraživanja su: (1) Osobine ličnosti sportiste su značajni prediktori sportske anksioznosti. Izražen neuroticizam, a niska ekstraverzija i savesnost jesu značajni prediktori somatske i kognitivne anksioznosti. Obrnut sklop osobina, nizak neuroticizam, visoka ekstraverzija i savesnost, povezani su sa sportiskim samopouzdanjem. (2) Postoje značajne polne razlike u izraženosti sport- ske anksioznosti. Žene ispoljavaju niži stepen sportskog samopouzdanja i veći stepen kognitivne i somatske anksioznosti u odnosu na muškarce. (3) Postoje značajne razlike u izraženosti sportske anksioznosti između sportista koji se bave individualnim i sportista koji se bave kolektivnim sportom. Veći stepen somatske anksioznosti i niže sportsko samopouzdanje, očekuju se kod sportista koji se bave individualnim sportom. (4) Postoje značajne razlike u izraženosti sportske anksioznosti u odnosu na nivo sportske uspešnosti. Vrhunski sportisti ispoljavanju veći stepen samopouzdanja i niži stepen kognitivne i somatske anksioznosti u odnosu na standardne sportiste i rekreativce.

\section{METODE}

\section{Uzorak entiteta}

Uzorak istraživanja činilo je 90 sportista iz Subotice, $62,2 \%$ muškaraca i 37,8\% žena; ispitanici su bili članovi 17 sportskih klubova. Uzrast ispitanika kretao se od 14 do 55 godina (Tabela 1).

\section{TABELA 1}

\begin{tabular}{|c|c|c|c|c|c|c|c|c|}
\hline Sex & $n$ & $\begin{array}{l}\text { Average } \\
\text { age }\end{array}$ & $\begin{array}{l}\text { Type of } \\
\text { sport }\end{array}$ & $n$ & $\%$ & $\begin{array}{c}\text { Level of sport } \\
\text { performance }\end{array}$ & $n$ & $\%$ \\
\hline Men & 56 & 21,55 & Collective & 48 & 53,33 & Outstanding athletes & 15 & 16,67 \\
\hline \multirow[t]{2}{*}{ Women } & 34 & 19,32 & Individual & 42 & 46,67 & Ordinary athletes & 60 & 66,67 \\
\hline & & & & & & Recreative athletes & 15 & 16,67 \\
\hline Total & 90 & 20,71 & & 90 & 100,00 & & 90 & 100,00 \\
\hline
\end{tabular}

Legenda: n - Broj ispitanika; \% - Procenat; Sex - Pol; Men - Muškarci; Womenn - Žene; Total - Ukupno; Average age - Prosjek godina; Type of sport - Vrsta sporta; Collective - Kolektivni; Individual - Individualni; Level of sport performance - Nivo sportske uspješnosti; Outstanding athletes - Vrhunski sportisti; Ordinary athletes - Prosječni sportisti; Recreative athletes - Rekretaivni sportisti.

\section{Uzorak varijabli}

U istraživanju se razlikuju nezavisne, odnosno, prediktorske varijable: a) demografske karakteristike ispitanika (pol ispitanika, uzrast, vrsta sporta, procena nivoa sportske uspešnosti) i b) osobine ličnosti; i kriterijumske varijable: kognitivna anksioznost, somatska anksioznost i samopouzdanje.

\section{Procedure testiranja}

Istraživanje je realizovano uz saradnju sportskih klubova. Istraživači su posjetili 20 sportskih klubova u Subotici i tom prilikom objasnili rukovodstvu klubova prirodu i cilj istraživanja. Po dobijanju sagla- snosti za istraživanje (od strane 17 klubova), realizovana je druga posjeta tokom koje je sportistima motivisanim da učestvuju u istraživanju, dat testovni materijal. Baterija instrumenata sastojala se od naslovne strane na kojoj su date osnovne informacije o istraživanju (koga sprovodi i sa kojim ciljem), informacije o tome kako će rezultati istraživanja biti korišćeni, kao i kontakt podaci autora istraživanja. Administriranje upitnika je bilo grupno, uz prisustvo istraživača.

U istraživanju su korišćena dva instrumenta: Competitive State Anxiety Inventory-2 (CSAI-2) (Martens i saradnici, 1990) sastoji se od 27 ajtema sa četvorostepenom skalom odgovora (uopšte ne, nešto malo, 
srednje, mnogo). Upitnik se sastoji od tri subskale: Kognitivna anksioznost ( 9 ajtema) koja se odnosi na očekivanje negativnog ishoda, neuspeha; somatska anksioznost (9 ajtema) odnosi se na tjelesne reakcije pred takmičenje i sportsko samopouzdanje ( 9 ajtema) odnosi se na vjeru u sebe i sopstvene sposobnosti. Koeficijenti pouzdanosti skala: Kognitivna anksioznost - $\alpha=0,83$, somatska anksioznost $-\alpha=0,86$, sportsko samopouzdanje - $\alpha=0,85$. Upitnik za procjenu bazičnih dimenzija ličnosti Velikih pet plus dva (VP+2) čiji su autori Smederevac i saradnici (2010). Upitnik se sastoji od 184 ajtema sa petostepenom skalom Likertovog tipa za odgovaranje. Upitnik se sastoji od sedam velikih skala (neuroticizam - 35 ajtema, ekstraverzija - 24 ajtema, savesnost - 28 ajtema, agresivnost - 30 ajtema, otvorenost - 20 ajtema, negativna valenca - 22 ajtema i pozitivna valenca - 25 ajtema)). Svaka od ovih skala sadrži dvije ili tri subdimenzije. Skala je namenjena ispitanicima starijim od 18 godina, stoga su u analizama isključeni sportisti mlađi od ovog uzrasta. U daljim analizama, kao mjera izraženosti osobina korišćeni su faktorski skorovi na prvim glavnim komponentama sedam navedenih skala. Koeficijenti pouzdanosti za svaku skalu ponaosob iznose: neuroticizam - $\alpha=0,88$, ekstraverzija $-\alpha=0,87$, savjesnost $-\alpha=0,63$, agresivnost $-\alpha=0,74$, otvorenost $\alpha=0,78$, pozitivna valenca $-\alpha=0,78$, negativna valen$\mathrm{ca}-\alpha=0,80$. Lista demografskih karakteristika - deo upitnika odnosi se na demografske varijable, to su: pol ispitanika, godine starosti, vrsta sporta (individualni/kolektivni), procena nivoa sportske uspešnosti od strane sportista (vrhunski sportista, standardni sportista i rekreativni sportista).

\section{Statistička analiza}

Od statističkih analiza upotrebljene su: deskriptivna statistika, multivarijantna analiza varijanse, višestruka regresiona analiza.

\section{REZULTATI}

\section{Osobine ličnosti kao prediktori kompetitivne anksioznosti}

Da li su osobine ličnosti (neuroticizam, ekstraverzija, savesnost, agresivnost, otvorenost ka iskustvu, negativna valenca i pozitivna valenca) značajni prediktori somatske anksioznosti, kognitivne anksioznosti i sportskog samopouzdanja, ispitano je višestrukom regresionom analizom. $U$ analizu su uključeni samo ispitanici stariji od 18 godina (ukupno 69 ispitanika). Rezultati analize pokazuju da su osobine ličnosti značajni prediktori somatske anksioznosti (Tabela 2), kognitivne anksioznosti (Tabela 3) i sportskog samopouzdanja (Tabela 4). Osobine ličnosti objašnjavaju $28 \%$ varijanse somatske anksioznosti, $44 \%$ varijanse kognitivne anksioznosti i $40 \%$ sportskog samopouzdanja.

\section{Polne razlike u izraženosti sportske an- ksioznosti (kognitivna i somatska anksi- oznost i sportsko samopouzdanje]}

Postojanje polnih razlika u izraženosti sportske anksioznosti ispitano je multivarijantnom analizom varijanse (Tabela 5). Rezultati pokazuju značajne polne razlike u nivou kognitivne anksioznosti, pri

\section{TABELA 2}

Znǎ́ajnost osobina ličnosti kao prediktora somatske anksioznosti.

\begin{tabular}{lccc}
\hline & $\beta$ & $t$ & $p$ \\
\hline Neuroticism & $-0,013$ & $-0,099$ & 0,922 \\
\hline Positive valence & 0,148 & 1,147 & 0,257 \\
\hline Conscientiousness & 0,046 & 0,353 & 0,726 \\
\hline Extroversion & $-0,022$ & $-0,171$ & 0,865 \\
\hline Aggressiveness & $-0,468$ & $-3,579$ & $\mathbf{0 , 0 0 1}$ \\
\hline Openness & 0,210 & 1,634 & 0,109 \\
\hline Negative valence & 0,052 & 0,398 & 0,692 \\
\hline \multicolumn{2}{c}{$R=0,529 ; R^{2}=0,279 ; F=2,493 ;$} & $p<0,05$
\end{tabular}

Legenda: $\beta$ - Beta standradizovani parcijalni doprinos; $\mathbf{t}$ - Studenova t distribucija; $\mathbf{p}$ - Vjerovatnoća; R - Koeficijent multiple korelacije; $\mathbf{R}^{2}$ - Koeficijent determinacije; F - Fišerov test utvrđivanja statističke značajanosti; Neuroticism - Neurotizam; Positive valenece - Pozitivna valenca; Conscientiousness - Savjesnost; Extrovertnost - Ekstraverzija; Aggressiveness Aggressiveness; Openness -Otvorenost; Negative valence - Negativna valenca. 


\section{TABELA 3}

Znǎ́ajnost osobina ličnosti kao prediktora kognitivne anksioznost.

\begin{tabular}{|c|c|c|c|}
\hline & $\beta$ & $t$ & $p$ \\
\hline Neuroticism & 0,250 & $-0,043$ & 0,033 \\
\hline Positive valence & $-0,005$ & $-1,698$ & 0,966 \\
\hline Conscientiousness & $-0,193$ & 0,742 & 0,096 \\
\hline Extroversion & 0,086 & $-3,887$ & 0,462 \\
\hline Aggressiveness & $-0,448$ & 2,101 & 0,000 \\
\hline Openness & 0,237 & $-0,054$ & 0,041 \\
\hline Negative valence & $-0,006$ & 2,198 & 0,957 \\
\hline
\end{tabular}

Legenda: $\beta$ - Beta standradizovani parcijalni doprinos; $\mathbf{t}$ - Studenova t distribucija; $\mathbf{p}$ - Vjerovatnoća; R - Koeficijent multiple korelacije; $\mathbf{R}^{2}$ - Koeficijent determinacije; F - Fišerov test utvrđivanja statističke značajanosti; Neuroticism - Neurotizam; Positive valenece - Pozitivna valenca; Conscientiousness - Savjesnost; Extrovertnost - Ekstraverzija; Aggressiveness Aggressiveness; Openness -Otvorenost; Negative valence - Negativna valenca.

\section{TABELA 4}

Značajnost osobina ličnosti kao prediktora sportskog samopouzdanja.

\begin{tabular}{|c|c|c|c|}
\hline & $\beta$ & $t$ & $p$ \\
\hline Neuroticism & 0,117 & 0,996 & 0,325 \\
\hline Positive valence & 0,120 & 1,028 & 0,310 \\
\hline Conscientiousness & 0,246 & 2,100 & 0,041 \\
\hline Extroversion & 0,017 & 0,142 & 0,888 \\
\hline Aggressiveness & 0,327 & 2,757 & 0,008 \\
\hline Openness & $-0,379$ & $-3,260$ & 0,002 \\
\hline Negative valence & 0,080 & 0,673 & 0,504 \\
\hline
\end{tabular}

Legenda: $\beta$ - Beta standradizovani parcijalni doprinos; $\mathbf{t}$ - Studenova t distribucija; $\mathbf{p}$ - Vjerovatnoća; R - Koeficijent multiple korelacije; $\mathbf{R}^{2}$ - Koeficijent determinacije; F - Fišerov test utvrđivanja statističke značajanosti; Neuroticism - Neurotizam; Positive valenece - Pozitivna valenca; Conscientiousness - Savjesnost; Extrovertnost - Ekstraverzija; Aggressiveness Aggressiveness; Openness -Otvorenost; Negative valence - Negativna valenca.

čemu žene ispoljavaju veći nivo kognitivne anksioznosti $\mathrm{M}_{\mathrm{w}}=19,82$ u poređenju sa muškarcima $\mathrm{M}_{\mathrm{m}}=17,06$.

Razlike u izraženosti sportske anksioznosti u odnosu na vrstu sporta (individualni/ kolektivni]

Analiza rezultata pokazuje značajne razlike u izraženosti somatske anksioznosti u odnosu na vrstu sporta - kolektivni/individualni. Nalazi pokazuju veći stepen somatske anksioznosti kod sportista koji se bave individualnim sportom u odnosu na one koji se bave kolektivnim sportom $\left(M_{i}=19,28 ; M_{c}=16,69\right)$. Nisu pronađane značajne razlike u izraženosti kognitivne anksioznosti i sportskog samopouzdanja u odnosu na vrstu sporta (Tabela 6).

\section{Razlike u izraženosti kompetitivne an- ksioznosti u odnosu na nivo sportske uspešnosti}

Rezultati MANOVA analize pokazuju značajne razlike u intenzitetu somatske anksioznosti i sportskog samopouzdanja u odnosu na nivo sportske uspešno- 


\section{TABELA 5}

Polne rąlike u iẓaženosti sportske anksioznosti.

\begin{tabular}{lrrrrc}
\hline & $M$ & $d f$ & $M S$ & $F$ & $p$ \\
\hline Cognitive anxiety & 152,553 & 1 & 152,553 & 5,306 & $\mathbf{0 , 0 2 4}$ \\
\hline Somatic anxiety & 94,599 & 1 & 94,599 & 3,072 & 0,083 \\
\hline Sports self-confidence & 84,633 & 1 & 84,633 & 3,221 & 0,076 \\
\hline
\end{tabular}

Legenda: M - Aritmetička sredina; df - Stepeni slobode; MS - Srednji kvadarat korigovane eritmetičke sredine; F - Fišerov test utvrđivanja statističke značajanosti; p - Vjerovatnoća; Cognitive anxiety - Kognitivna anksioznost; . Somatic anxiety - Somatska anksioznost; Sports self-confidence - Sportsko samopuzdanje.

\section{TABELA 6}

Polne rąlike u izraženosti sportske anksioznosti.

\begin{tabular}{lrrrrc}
\hline & $M$ & $d f$ & \multicolumn{1}{c}{$M S$} & $F$ & \multicolumn{1}{c}{$p$} \\
\hline Cognitive anxiety & 11,393 & 1 & 11,393 & 0,374 & 0,543 \\
\hline Somatic anxiety & 140,494 & 1 & 140,494 & 4,646 & $\mathbf{0 , 0 3 4}$ \\
\hline Sports self-confidence & 1,016 & 1 & 1,016 & 0,037 & 0,847 \\
\hline
\end{tabular}

Legenda: M - Aritmetička sredina; df - Stepeni slobode; MS - Srednji kvadarat korigovane eritmetičke sredine; F - Fišerov test utvrđivanja statističke značajanosti; p - Vjerovatnoća; Cognitive anxiety - Kognitivna anksioznost; . Somatic anxiety - Somatska anksioznost; Sports self-confidence - Sportsko samopuzdanje.

\section{TABELA 7}

Kompetitivna anksioznost $i$ nivo sportske uspeřnosti

\begin{tabular}{lccccc}
\hline & $M$ & $d f$ & $M S$ & $F$ & $p$ \\
\hline Cognitive anxiety & 199,661 & 1 & 99,830 & 3,500 & 0,035 \\
\hline Somatic anxiety & 348,893 & 1 & 174,446 & 6,222 & $\mathbf{0 , 0 0 3}$ \\
\hline Sports self-confidence & 278,250 & 1 & 139,125 & 5,748 & $\mathbf{0 , 0 0 5}$ \\
\hline
\end{tabular}

Legenda: M - Aritmetička sredina; df - Stepeni slobode; MS - Srednji kvadarat korigovane eritmetičke sredine; F - Fišerov test utvrdivanja statističke značajanosti; p - Vjerovatnoća; Cognitive anxiety - Kognitivna anksioznost; . Somatic anxiety - Somatska anksioznost; Sports self-confidence - Sportsko samopuzdanje.

sti (Tabela 7). Razlike su pronađene između vrhunskih i standardnih sportista, dok razlike nisu potvrđene na uzorku rekreativaca. Vrhunski sportisti izveštavaju o nižem intenzitetu somatske anksioznosti i većem sportskom samopouzdanju u odnosu na standardne sportiste (somatska anksioznost - $M_{\sigma}=14,6 ; M_{s}=19,3$; sportsko samopouzdanje $\mathrm{Mo}=30,6 ; \mathrm{Ms}=25,9)$.

\section{DISKUSIJA}

Uzimajući u obzir sve veću orjentaciju na uspjeh i postignuće u sportu, veliko je interesovanje istraživača za utvrdivanje svih faktora koji tome doprinose. Istraživanja kontinuirano potvrđuju anksioznost kao jedan od faktora koji negativno utiče na postignuće sportiste (Behzadi i saradnici, 2011; Pineda-Espejel i saradnici, 2011). U ovom istraživanju je korišćen multidimenzionalni konstrukt anksioznosti koji obuhvata somatsku i kognitivnu anksioznost i sportsko samopouzdanje. Nalazi pokazuju da nivo sportske anksioznosti zavisi od više faktora - određenih osobina ličnosti, pola, vrste sporta, nivoa sportske uspješnosti itd.

Kao značajni prediktori sportske anksioznosti, istakle su se osobine ličnosti sportiste. Agresivnost se pokazala kao značajan negativan prediktor somatske i kognitivne anksioznosti, a pozitivan prediktor sportskog samopouzdanja. Sportisti koji ispoljavaju ovu 
osobinu, imaju emocionalnu predispoziciju za burno, impulsivno reagovanje, često su nametljivi i arogantni, sa snažnom željom da dominiraju (Smederevac i saradnici, 2010). Stoga ne iznenađuje njihovo povišeno samopouzdanje i izostanak zabrinutosti oko potencijalnog neuspeha. Nalaz koji je u skladu sa očekivanjima i nalazima prethodnih istraživanja jeste Neuroticizam kao značajan prediktor kognitivne anksioznosti. Kao značajan prediktor kognitivne anksioznosti izdvojila se i otvorenost ka iskustvu. Neuroticizam, odnosno emocionalna nestabilnost, odnosi se na sklonost doživljavanja negativnih emocija, a sam aspekt neuroticizma jeste upravo anksioznost (Ibid), pa je očekivana povezanost ove osobine sa sportskom anksioznošću sportiste. Otvorenost ka iskustvu, iako podrazumeva radoznalost, širok krug interesovanja i sl., ukoliko je veoma izražena, podrazumjeva i neopreznost koja može biti ključna za postizanje uspjeha ili neuspjeha. Kao značajni prediktori sportskog samopouzdanja izdvojili su se otvorenost prema iskustvu i savjesnost. Osobu koja ima izraženu osobinu savjesnosti karakterišu samokontrola, disciplina, ulaganje napora u ostvarivanje ciljeva (Ibid). Može se pretpostaviti da će ovakav sportista ulagati veliki trud i napor u treniranje, koje će za rezultat imati i veće samopouzdanje u sopstvene sposobnosti. Sa druge strane, otvorenost ka iskustvu, kao negativan prediktor sportskog samopouzdanja, podrazumijeva široka interesovanja, stalno traganje za senzacijama, pa je teško zamisliti ovakvog sportistu da bude istrajan u treniranju i da istovremeno svoja interesovanja i energiju usmjeri isključivo na sport. Samim tim, ova osobina može doprinjeti nesigurnosti na polju sportske kompetencije.

Iako se može pretpostaviti postojanje povezanosti između osobine i njenog pripadajućeg stanja (npr. crta i stanje anksioznosti), ovakvi nalazi mogu biti posljedica činjenice da instrument VP+2 mjeri crte ličnosti, a CSAI-2 mjeri stanje anksioznosti. Relacije bi bile uvjerljivije da je u istraživanju mjerena crta anksioznosti.

U skladu sa očekivanjima i prethodnim istraživanjima, žene ispoljavaju veći stepen kognitivne anksioznosti (Humara, 1999; Pineda-Espejel i saradnici, 2011). Žene, u većoj mjeri od muškaraca, procjenjuju situaciju takmičenja (evaluativna situacija) kao ugrožavajuću, a ne kao izazovnu (Cassady i Johnson, 2002), što rezultuje većim nivoom kognitivne anksioznosti. Takođe, istraživanja pokazuju da su psihološki faktori značajniji prediktori postignuća sportistkinja, u odnosu na sportiste (Matsumoto i saradnici, 2000). Međutim, važno je naglasiti da uzorak ispitanika nije bio ujednačen po polu, u ispitivanju je učestvovalo 56 muškaraca i 34 žene, stoga bi ovo ograničenje trebalo biti korigovano u budućim istraživanjima.

Veći stepen somatske anksioznosti potvrđen je na uzorku sportista koji se bave individualnm sportom, u odnosu na one koji se bave kolektivnim sportom. Objašnjenje ovakvih nalaza jeste u podeljenoj odgovornosti kod sportista koji se bave kolektivnim sportom, dok je u individualnom sportu, odgovornost na pojedincu. Očekivan nalaz jeste i veći stepen sportskog samopouzdanja i niži stepen somatske anksioznosti kod vrhunskih sportista, u poređenju sa standardnim sportistima. Vrhunski sportisti postižu bolje rezultate, samim tim imaju i više samopouzdanja. Istraživanja pokazuju da sportisti koji sebe procjenjuju kao sposobne za ostvarenje ciljeva, koji imaju visok nivo sportskog samopouzdanja, procjenjuju simptome anksioznosti kao podstičuće (Pineda-Espejel i saradnici, 2011). Razlike nisu pronađene na uzorku rekreativaca, s obzirom da se oni ne susreću sa takmičarskim situacijama. U skladu sa tim, kod njih se može očekivati i nizak nivo sportske anksioznosti. Međutim, treba uzeti u obzir da su ispitanici sami procjenjivali nivo sportske uspešnosti (vrhunski/standardni sportista/rekreativac), kao i činjenicu da uzorak nije ujednačen po ovoj varijabli (vrhunski sportisti - 15 ispitanika, standardni - 60, rekreativci - 15). U skladu sa tim, može se i očekivati da sportisti koji sebe procjenjuju kao vrhunske imaju veći nivo sportskog samopouzdanja i povjerenje u vlastite sposobnosti.

\section{ZAKLJUČAK}

Dobijeni nalazi su značajni, ne samo za istraživače radi boljeg razumevanja anksioznosti u sportskom kontekstu, već i za praktičare, za trenere i same sportiste. Rezultati istraživanja mogu pomoći sportistima i trenerima da preduprjede sve faktore koji utiču na anksioznost sportiste, a sve u cilju boljeg sportskog postignuća. Ovo istraživanje se bavilo anksioznošću kao stanjem; predlog za buduća istraživanja odnosi se na uvođenje anksioznosti kao crte ličnosti i ispitivanje njenog značaja za sportsko postignuće. Kako se može pretpostaviti da će sportista koji poseduje samopouzdanje, biti i uspešniji u sportskim situacijama takmičenja, bilo bi korisno ispitati i vezu nekih drugih faktora značajnih za samopouzdanje sportiste (npr. trenerski stil) sa sportskim postignućem. Dalja istraživanja u ovoj oblasti su neophodna kako bi se u potpunosti razumjeo način na koji psihološki faktori utiču na postignuće sportiste, odnosno, kako bi se pomoglo sportistima u eliminisanju faktora koji ometaju potpunu realizaciju njihovih potencijala. 


\section{LITERATURA}

Behzadi, F., Hamzei, M., Nori, S., \& Salehian, M. H. (2011). The Relationship between goal orientation and competitive anxiety in individual and team athletes fields. Scholars Research Library, 2, 261-268.

Bridges, A., \& Knight, B. (2005). The role of cognitive and somatic anxiety in athletic performance. Hanover, Germany: Hanover College.

Craft, L. L., Magyar, T. M., Becker, B. J., \& Feltz, D. L. (2003). The relation between the competitive state anxiety inventory-II and sport performance: A meta-analysis. Journal of Sport and Exercise Psychology, 25, 44-65.

Dunn, J. G. H., \& Dunn, J. C. (2001). Relationships among the sport competition anxiety test, the sport anxiety scale, and the collegiate hockey worry scale. Journal of Applied Sport Psychology, 13(4), 411-429. doi: 10.1080/104132001753226274

Feltz, D. (1988). Self-confidence and sport performance. Exercise and Sport Science Reviews, 16, 423-457. doi: 10.1249/00003677198800160-00016

Gershuny, B. S., \& Sher, K. J. (1998). The relation between personality and anxiety: Findings from a 3-year prospective study. Journal of Abnormal Psychology, 107(2), 252-262. doi: 10.1037/0021843X.107.2.252; PMid:

Gould, D., Petlichkoff, L., \& Weinberg, R. S. (1984). Antecedents of temporal changes in, and relationships between CSAI-2 subcomponents. Journal of Sport Psychology, 6, 289-304.

Hardy, L. (1996). A test of catastrophe models of anxiety and sports performance against multidimensional anxiety theory models using the method of dynamic differences. Anxiety, Stress and Coping. 9, 69-86.

Hardy, C., \& Crace, K. (2009). Dealing with precompetitive anxiety. Sport Psychology Training Bulletin, 3513-3517. doi: 10.1080/10615809608249393

Humara, M. (1999). The relationship between anxiety and performance: A cognitive behavioral perspective. The Online Journal of Sport Psychology, $1,1-14$.

Jones, G., Swain, A. B. J., \& Cale, A. (1991). Gender differences in precompetition temporal patterning and antecedents of anxiety and selfconfidence. Journal of Sport and Exercise Psychology, 13, 1-15.
Kirby, R. J., \& Liu, J. (1999) Precompetition anxiety in chinese athletes. Perceptual and Motor Skills, 88(1), 297-303. doi: 10.2466/pms.1999.88.1.297

Knežević, G., Radović, B., \& Opačić G. (1997). Evaluacija "Big Five" modela ličnosti kroz analizu inventara ličnosti NEO PI-R [Evaluation of the »Big Five« model of personality through analysis of personality inventory NEO PI-R]. Psibologija, 30(1-2), 7-40.

Komarraju, M., Karau, S. J., \& Schmeck, R. R. (2009). Role of the Big Five personality traits in predicting college students' academic motivation and achievement. Learning and Individual Differences, 19(1), 47-52. doi: 10.1016/j. lindif.2008.07.001

Marić, M. (2010). Osobine ličnosti, životni događaji i anksioznost adolescenata [Personality traits, life events and adolescent anxiety]. Primenjena psibologija, 19(1), 39-57.

Martens, R., Burton, D., Vealey, R. S., Bump, L. A., $\&$ Smith, D. E. (1990). Development and validation of the competitive state anxiety inventory-2. In R. Martens, R.S. Vealey, \& D. Burton (Eds.), Competitive Anxiety in Sport (pp. 117-190). Champaign, IL: Human Kinetics.

Matsudaira, T., \& Kitamura, T. (2006). Personality traits as risk factors of depression and anxiety among Japanese students. Journal of Clinical Psychology, 62(1), 97-109. doi: 10.1002/ jclp.20215; PMid: 16287151

Matsumoto, D., Takeuchi, M., Nakajima, T., \& Iida, E. (2000). Competition anxiety, self-confidence, personality and competition performance of american elite and non-elite judo athletes. Research Journal of Budo, 32(3), 12-21.

Middeldorp, C. M., Cath, D. C., van den Berg, M., Beem, A. L.,van Dyck, R., \& Boomsma, D. I. (2006). The association of personality with anxious and depressive psychopathology. In T. Canli, (Ed.), Biology of personality and individual differences (p.p. 254-272). New York, NY: The Guilford Press.

Pineda-Espejel, A., López-Walle, J., Rodríguez, J. T., Villanueva, M. M., \& Gurrola, O. C. (2011). Precompetitive Anxiety and Self-confidence in Pan American Gymnasts. Science of Gymnastics Journal, 5(1), 39-48.

Smederevac, S., Mitrović, D., \& Čolović, P. (2010). Velikih pet plus dva [The big five plus two]. Belgrade, Serbia: Centar za primenjenu psihologiju. 
Tran, X. (2012). Football Scores on the Big Five Personality Factors across 50 States in the U.S. Sports Medicine \& Doping Studies, 2(6), 1-5.

Vujanović, S., \& Tišma, M. (2011). Povezanost kompetitivne anksioznosti i efikasnosti sportista
[Correlation between competitive anxiety and efficacy of athletes]. Aktuelno u praksi, 23(10), 31-41.

Primljeno: 12. mart 2014 Izmjene primljene: 22. maj 2014

Odobreno: 26. juna 2014

Korespondencija: mr Dejana Velikić

Visoka škola strukovnih studija za obrazovanje vaspitača i trenera

Banijska 57

24000 Subotica

Srbija

Telefon: 00381606338810

E-mail: dejana.velikic@gmail.com 